\title{
Anatomia do entusiasmo \\ Cultura e revolução em Cuba (1959-1971)
}

\author{
Rafael Rojas \\ Tradução de Fernando Pinheiro
}

O sdozeanos quevão do triunfo da Revolução C ubana, em janeiro de1959, ao início da institucionalização soviética da ilha, em 1971, podem catalogarse como os mais dinâmicos sob o ponto de vista cultural e ideológico da experiência cubana e de boa parte da história intelectual latino-americana do século XX. N aquela década não só se produziu o confronto entre noções de cultura liberais, católicas e marxistas como, dentro do próprio campo socialista, teve lugar um intenso debate entre concepções stalinistas e libertárias da produção intelectual. 0 objetivo deste ensaio é recapitular as maisimportantes polêmicas intel ectuais daquela década, queultrapassam o campo cultural da ilha e envolvem boa parte da esquerda ocidental, por meio das principais publicações cubanas (Lunes de Revolución, La Gaceta de Cuba, Casa de lasAméricas, U nión, El Caimán Barbudo, Pensamiento Crítico) e também das poéticas plasmadas na narrativa, na poesia, no teatro, no cinema, nas artes plásticas eno pensamento produzido na ilha'.

0 triunfo da Revolução, em janeiro de 1959, produziu-senum momento de esplendor da cultura cubana. Três grandes músicos do século $X X$, Ernesto Lecuona, Benny M orée Bola deN ieve, produziam então o melhor de suas obras. As artes plásticas, como se vê ao percorrer os "salões anuais" de 1959 e 1960, reuniam grandes pintores eescultores do século XX: Amelia Palaez, René Portocarrero, M ariano Rodríguez, Cundo Bermúdez, José M ijares, Rafael Soriano... (cf. Veigas et al., 2002, pp. 420-424). 0 teatro

1.N as duas últimas décadas o tema tem sido documentado por um bom número de estudos, entre os quais menciono apenas alguns: Verdés-Leroux (1989); Quintero Herencia (2002); Gilman (2003); Franco (2004); M artínez Perez (2006); Rojas (2006). 
havia al cançado sua mais plena institucional ização e uma nova indústria, a cinematográfica, nascia com pleno respaldo do governo revolucionário (cf. García Borrero, 2001, pp. 20-45). Apenas dois anos depois, um daqueles músicos estava morto e outro havia se exilado, junto com três dos pintores mencionados. Carpentier captou magistralmenteo momento dessa fratura:

E te perguntas por que foram fechadas as câmaras literárias de $N$ antes? D eu um soco na mesa: Estamos mudando a face do mundo, mas só te preocupa a má qualidade de uma peça teatral. Estamos transformando a vida do homem, mas se doem de que alguns letrados não possam reunir-se para ler idílios e leviandades. Seriam capazes de poupar a vida de um traidor, de um inimigo do povo, contanto que tivesse escrito belos versos! (1984, p. 112).

Assim falava Victor Hugues, o caudilho revolucionário, a Esteban, 0 escritor, no pavimento de um barco que transportava os ideais da Revolução Francesa - etambém sua máquina incansável, a guil hotina - atéasilhas do $\mathrm{C}$ aribe. Essa passagem deEI siglo delas luces, de Alejo C arpentier, ilustra o momento em que os políticos e os intelectuais de uma revolução põem em confronto suas prioridades. Para os primeiros, a literatura, a arte, a moral, o teatro, a filosofia, enfim, a cultura, einclusive a ideologia, são esferas que, em circunstâncias prementes - e toda revolução é sempre uma circunstância premente - , passam para segundo plano ou se tornam obstinados estorvos. Para os segundos, a revolução social e política deve-se a uma mudança axiomática na cultura, cujos promotores e intérpretes mais bem dotados são eles mesmos. 0 sacrifício das práticas culturais, no altar das tarefas urgentes do Estado, parece a essas testemunhas ideais uma degradação da própria ordem revolucionária.

N os primeiros anos de toda revolução dá-se uma espécie de encantamento recíproco entre intelectuais e políticos, que, chegado o momento, se desfaz bruscamente por meio de uma implacável lógica saturnina. $\mathrm{N}$ a França, Louis D avid, AndréC henier, Phillipe Fabree Camille D esmoulins celebram, com suas pinturas, odes e calendários neoclássicos, o advento da República (cf. Starobinski, 1988, pp. 55-68). O strês poetas seriam guilhotinados duranteo Terror, enquanto $\mathrm{D}$ avid, depois deter contribuído para 0 que Fabre chamava de "império das imagens" jacobinas, transforma-se em pintor oficial da nova corte de $\mathrm{N}$ apoleão I. $\mathrm{O}$ utros intelectuais do antigo regime, que graças a suas idéias ilustradas viram com simpatia o evento revolucionário, como $\mathrm{M}$ alherbes $\mathrm{C}$ ondorcet, refugiaram-seem seus caste- 
los ou abandonaram o país. D e modo que as alternativas dos intelectuais franceses, a partir de 1794, eram claras: 0 exílio, o oportunismo ou a morte.

$\mathrm{N}$ a Rússia de 1917 também se observa esse deslumbramento da intelectualidade diante do frenesi revolucionário. G orki e Pasternak, M aiakovsky e $M$ andelshtam, Esenin e Ajmatova assumem a poesia como um canto de consagração do Estado bolchevique. A penas sete anos depois, morto Lênin e todo o poder nas mãos de Stalin, dois deles haviam se suicidado e os outros quatro passam a uma espécie de exílio interior - isso que Cabrera Infante chamaria de inślio ${ }^{2}$ - que os converte em fantasmas de sua própria cultura. Falando, justamente, da Revolução de 0 utubro, François Furet se pergunta: "Por que resulta tão fascinante aos intelectuais a catarse revolucionária?". A resposta do historiador francês merece um comentário:

A revolução recupera em seu arsenal ideológico esse substituto da religião que tanta falta faz à Europa desde o fim do século XVIII. M isturando o desprezo pela lógica com dois elixires por excelência modernos - 0 voluntarismo jacobinopopulista e o determinismo histórico marxista - , compõe uma bebida forte 0 bastante para embriagar várias gerações de militantes (Furet, 1995, p. 77).

$M$ as as grandes revoluções não causam estremecimento apenas nos intelectuais dos países em que ocorrem. Tais acontecimentos produzem o que Furet chama de um "feitiço universal" na cultura moderna (cf. Idem, p. 113). Por um momento, o transtorno revolucionário deixa deser assunto de um país para converter-se em um signo da mudança mundial. Por isso a Revolução Francesa cativa alemães como Emmanuel Kant, ingleses como Thomas Paine enorte-americanos como Benjamin Franklin. A Revolução Russa seduz as mentes deH . G. Wells, AndréG ide, Romain Rolland, André M alraux, Louis Aragon, Aldous H uxley, Bertold Brecht. Por fim, a Revolução Cubana ganha a simpatia deal guns escritores ocidentais degrande prestígio, como Jean-Paul Sartre, $\mathrm{H}$ erbert $\mathrm{M}$ arcuse, $\mathrm{H}$ ans $\mathrm{M}$ agnus Enzensberger, Charles Wright M ills, Waldo Frank, Allen Ginsberg, e de quase toda a intelectualidade latino-americana: 0 ctavio Paz, M ario Vargas Llosa, Gabriel G arcía M árquez, Julio C ortázar. Q uando o pacto entreosintelectuaise o poder se rompe, esses espectadores, salvo raras exceções, retiram seu apoio à revolução e se convertem em seus críticos mais pertinazes.

No caso da Revolução Cubana, o romance entre o intelectual e o poder durou um pouco mais; talvez uns dez anos. Com a queda do ditador Fulgencio Batista, em 1959, três gerações de intelectuais aplaudiram a vi-
2. No original, o neologismo insilio (N.T.). 
3. Ver o capítulo "The PhoneyTruce" em Reed (1991, pp. 67-98).

4. Essa idéia se plasma claramente em M arinello (1984a, pp. 90107; 1984b, pp. 273303).

5.Sigo aqui a clássica idéia de Gramsci em La política y el Estado moderno (1971, p. 67). tória do Exército Rebelde e ofereceram seus serviços ao jovem governo revolucionário: a geração dos anos de 1930, com suas alas comunista e reformista claramente delineadas desde os tempos da Revista de Avance; a dos anos de 1940, cujo projeto cultural mais significativo foi a revista O rígenes; e a dos de 1950, que poderia associar-se em certa medida às plataformas estéticas da Sociedad N uestro Tiempo e da revista Ciclón. A primeira e a terceira gerações eram integradas por intelectuais públicos, que se moviam dentro das referências culturais de uma política moderna. O s poetas de 0 rígenes, em vez disso, haviam articulado um profundo imaginário nacional à margem dos debates sobre a modernidade cubana (cf. Rojas, 1999, pp. 73-86 e 188-197). Isso explica, de algum modo, que 0 confronto dos anos de 1960 tivesse sido protagonizado, fundamentalmente, pelos escritores dos anos de 1930 e de 1950, ainda que até mesmo José Lezama Lima e os poetas católicos de 0 rígenes, em algum momento, tenham sido convocados pelos jovens intelectuais de Lunes de Revolución e, logo, depois do caso Padilla e do Congresso Nacional de Educação e Cultura de 1971, sofressem um ostracismo forçado pelo regime 3 .

O s comunistas cubanos queainda viviam em 1959 (JoséZacaríasTallet, Juan M arinello, N icolás G uillén, Regino Pedroso, Alejo Carpentier) viram a Revolução como o desenlace político do movimento cultural vanguardista que haviam protagonizado três décadas antes. Esse grupo contava com uma nova geração de escritores e dirigentes que podia oferecer ao governo revolucionário todo um programa de renovação cultural eeducativa: $C$ arlos Rafael Rodríguez, JoséAntonio Portuondo, Félix Pita Rodríguez, Blas Roca, M irta Aguirre, Aníbal Escalante, Joaquín O rdoqui, Edith García Buchaca. Sem dúvida, essa corrente, filiada ao Partido Socialista Popular, era a de maior consistência ideológica no momento do triunfo da Revolução. De fato, todos os seus membros eram intelectuais eao mesmo tempo políticos; ou seja, eram intelectuais orgânicos desse "M oderno Príncipe" nascido em 1 o de janeiro de $1959^{5}$. M as o vínculo orgânico que haviam estabelecido com seu partido devia agora ser transferido para um governo revolucionário em que convergiam várias organizações políticas, cujos repertórios ideológicos não eram propriamente marxista-leninistas.

A princípio, essa delegação de autoridade não parecia gerar muitas dificuldades. Blas Roca, que era secretário geral do Partido Socialista, entregou o poder e a autonomia de sua organização ao governo revolucionário. 0 mesmo fizeram os dirigentes do Diretório Estudantil U niversitário e do M ovimento 26 de Julho. Com o desaparecimento dessas três organizações, 
quehaviam capitalizado a luta contra Batista, deu-sea possibilidade de configurar-se um partido único estatal. 0 governo logrou seu intento primeiro com as 0 rganizações R evolucionárias Integradas (O RI), depois com o Partido U nido da Revolução Socialista (PU RS) e, finalmente, com o Partido Comunista de Cuba, quefoi criado em 1965. Esses três passos respondem a um objetivo claramentedelineado pelo poder revolucionário desdeseus primeiros dias: a dissolução de todas as diferenças ideológicas e políticas que haviam integrado o amplo espectro da oposição a Batista (cf. Stable, 1998, pp. 175-177). Ainda quetambém, desdeao menoso segundo ano da Revolução, a confluência daquelas associações num Partido Comunista perseguiaum fim geopolítico: assegurar umaaliança com aU RSS, queprotegeria Cuba no caso de verificar-se a anunciada intervenção norte-americana (cf. Ruiz, 1972, pp. 147-148).

0 processo de unificação, entretanto, não foi nada cômodo. C ada organização sobrevivia a seu modo dentro do partido e do governo. O s comunistas, que eram o único grupo possuidor deum projeto econômico, cultural e ideológico bem perfilado, chamaram a si, com o beneplácito de Fidel C astro, o controle da economia, da política e da cultura do país. Sobretudo a partir de 1961, essa inserção nas posições estratégicas do governo tornouse visível para o restante da nova elite, levantando uma onda de rancores nos outros grupos (cf. D omínguez, 1978, pp. 320-322). Carlos Rafael Rodríguez foi nomeado presidente do Instituto $\mathrm{N}$ acional da Reforma Agrária (Inra), que, mais que uma agência econômica, era uma espécie de Conselho de Estado virtual. Aníbal Escalante manejava a mesa diretora das O RI e depois também do PURS. Joaquín O rdoqui, além de membro da direção nacional dessas duas organizações, era vice-ministro das Forças Armadas. O utro comunista, Augusto M artínez, foi designado ministro do Trabal ho. $\mathrm{N}$ icolás Guillén era já o presidente da U neac (U nión de Escritores y Artistas de Cuba); Alejo C arpentier, diretor da Imprensa N acional; Edith G arcía Buchaca, como uma das vice-presidentes do Conselho $\mathrm{N}$ acional de Cultura, lograva um efetivo controle daquela importante instituição que, demodo mais honorífico, era encabeçada por Vicentina Antuña (cf. C abrera Infante, 1993, p. 102).

$M$ as 0 acesso desses intelectuais ao governo, habilmente pactuado entre Fidel $C$ astro e a direção do PSP, teria seus custos para os próprios comunistas. Q uando se cria o Partido Comunista em 1965, três importantes líderes do velho PSP já haviam sido expulsos desonrosamente da classe política cubana: Aníbal Escalanteem 1962, por ocasião do processo de sectarismo; 
e Joaquín O rdoqui e Edith García Buchaca por ocasião do chamado C aso $M$ arquitos (cf. $\mathrm{H}$ abel, 1965, pp. 7-20). Esses expurgos e ainda um terceiro, o da "M icrodivisão", em 1967 - ainda que estivessem baseados no receio anticomunista dos líderes de outras organizações revolucionárias, como 0 M ovimento 26 de Julho e, sobretudo, o Diretório Estudantil -, refletiramse na cultura por meio de polêmicas que delinearam o tipo de intelectual orgânico desejável para o novo poder. Fazendo a economia sociológica daquele amplo debate dos anos de 1960, pode-se dizer que os antagonistas eram o Intelectual $\mathrm{N}$ acionalista Revolucionário e o Intelectual Comunista Revolucionário. $\mathrm{N}$ a recente nomenklatura da ilha, o primeiro arquétipo seria encarnado por $\mathrm{C}$ arlos Franqui, diretor do periódico Revolución, $\mathrm{H}$ aydée Santamaría, diretora da C asa de las Américas, Alfredo Guevara, diretor do Icaic, eArmando $\mathrm{H}$ art, ministro da Educação. $\mathrm{O}$ segundo, por outro lado, seria o modelo intelectual dos cinco célebres sobreviventes do PSP: Blas Roca, Juan M arinello, C arlos R afael Rodríguez, M irta Aguirre e J osé Antonio Portuondo.

A disputa entreo Intelectual $\mathrm{N}$ acionalista eo Intelectual C omunista, que cancelava em sua origem a possibilidade de um Intelectual Republicano ou D emocrático - cujas figuras emblemáticas haviam se exilado nos primeiros anos (J orge M añach, Roberto Agromonte...) ou envelheciam caladas nailha (Ramiro Guerra, Fernando 0 rtiz...) - , permeou toda a década de 1960 em Cuba e, longe de refletir uma quebra política entre as elites, centrou-se asceticamente nos temas morais da cultura. 0 s paradigmas enfrentaram-se na polêmica sobre os filmes $L$ a dolce vita e Accatone, de Federico Fellini, entre Blas Roca e Edith G arcía Buchaca, de um lado, e Alfredo Guevara e Tomás G utiérrez Alea, deoutro, queenvolveu as publicações H oy, La G aceta deCuba, Cuba Socialista eRevolución, eno questionamento bastante difundido do realismo socialista como método de criação paraa literaturaeasartes (cf. Idem, pp. 7-10). Q uase todos os jovens intelectuais nacionalistas dos anos de 1950, próximos da Sociedad N uestro Tiempo ou das revistas $N$ ueva Generación, Ciclón eLunesde Revolución, como Guillermo C abrera Infante, H eberto Padilla, Antón Arrufat, Edmundo D esnoes, Roberto Fernández Retamar, Lisandro 0 tero, Pablo Armando Fernández ou Ambrosio Fornet, opuseram-se à adoção daquele cânone estético formulado por Andrei Zhdanov paraa Rússia deStalin, queera promovido mais ou menos abertamente pelos vel hos comunistas (cf. Reed, 1991, pp. 67-97).

As críticas de Che Guevara ao realismo socialista em El socialismo y el hombre en Cuba (1965) caíram como uma bênção naquele círculo intelec- 
tual. M as o vanguardismo político de G uevara acenavatanto para a rei vindicação como para o desprezo da classeintelectual. 0 C he reconhecia queessa "idealização do presente", promovida pelo funcionalismo stalinista, ainda não se manifestara na C uba de meados dos anos de 1960 (cf. C he Guevara, 1971, p. 116). O bservava, em troca, quea cultura cubana desses anos incorria freqüentementeem um "erro designo contrário": a "alienação", o "passatempo vulgar", a "angústia sem sentido", o "anúncio do cadáver fétido do capitalismo", a "jaula invisível do idealismo burguês", a "morbidez e a decadência do século XX..." (I dem, pp. 115-117). Todos esses sintomas culturais, segundo 0 Che, emergiam do "pecado original" ou da "culpabilidade" dos intelectuais e artistas cubanos: "N ão ser autenticamente revolucionários" (I dem, p. 118). Por isso a "tarefa" da nova classe política era "impedir" que aquela geração intelectual, "deslocada por seus conflitos, pervertesse as novas" (I dem, p. 118). Essa moralidade genética não só chegou a difundir-se entre os líderes políticos como também entre os próprios intelectuais, que projetaram em suas obras o complexo de cul pa de não haver participado da Revolução. Grande parte do discurso laudatório sobre feitos e heróis de gesta, que se acumularam nesses anos, éo resultado textual dessa projeção.

U ma vez criado o regime de partido único, naquele ano de 1965, as tensões entre $\mathrm{o}$ Intelectual $\mathrm{N}$ acionalista e $\mathrm{o}$ Intelectual Comunista puderam ventilar-se dentro do campo de liberdade assegurado pelo Estado. A maior dificuldade do poder residia no fato de que, se todos os comunistas eram nacionalistas - no estrito sentido antiamericano quetem o nacionalismo em Cuba - , nenhum nacionalista era propriamente comunista e alguns eram francamente anticomunistas. C arlos R afael Rodríguez, por exemplo, captou a dificuldade dessa justaposição ao expor, em 1965, o dilema de sua própria leal dade em uma entrevista ao The N ew York Times: "Q ual é a lealdade principal de um revolucionário" - perguntava-Ihe Lyle Stuart - "a Fidel ou ao Partido?". E Carlos Rafael respondia: "Pode ser que muitos em Cuba pensem mais em termos de Fidel que em termos de Partido. Para nós, no entanto, Fidel e o Partido são a mesma coisa... Para nós essa leal dade a Fidel e ao Partido é a mesma lealdade" (Rodríguez, 1983, v. 2, pp. 437438). D a perspectiva de um comunista com disciplina partidária, como C arlos Rafael Rodríguez, a lealdade a Fidel, e não ao Partido, que muitos nacionalistas revolucionários mostravam, era um tipo precário de compromisso político, associado ao "populismo pequeno-burguês", que devia evoluir até a forma superior de consciência de classe que implicava a lealdade ao Partido Comunista. 
6. Em sua resenha de Retrato de familia con Fidel, Cabrera Infante (1993, pp. 281-293) realiza um interessante esboço biográfico de Franqui.
N o outro pólo da geografia intelectual, esseétambém o dilema deCarlos Franqui. Em sua juventude, Franqui havia militado no Partido Socialista Popular, chegando a trabal har como redator no periódico H oy. Já distante dessa organização no início dos anos de 1950, criou a sociedade cultural N uestro T iempo, filiou-se ao M ovimento 26 de Julho e, assim como $\mathrm{C}$ arlos Rafael Rodríguez, lançou-se na Sierra M aestra e fundou a Rádio Rebelde e o periódico Revolución, os dois principais meios de comunicação da insurreição contra Batista6. Atrás do triunfo revolucionário de janeiro de 1959, Franqui converteu-se em um dos protótipos do intelectual nacionalista, receoso tanto da ingerência norte-americana como da soviética e defensor de uma cultura crítica, antiburocrática, dentro das elites revolucionárias. L unes de Revolución, a visita de Sartre, o Salão de M aio, o Congresso Cultural de $\mathrm{H}$ avana e boa parte da audaz política editorial dos anos de 1960 deveram-se à persuasiva interlocução de Franqui com os novos políticos profissionais. Ainda em 1972, recém-exilado, em um texto para a revista Libre, Franqui, por seu acentuado anti-sovietismo, não podia declarar-se leal ao Partido Comunista de Cuba, mas, em troca, era capaz de mostrar adesão à figura de Fidel C astro e à de C he Guevara, e de simpatizar com todos os socialismosindependentes deM oscou, desdeo chinêse o vietnamita até o iugoslavo e o romeno (cf. Franqui, 1972, pp. 9-10).

Assim, o comunista Rodríguez e o nacionalista Franqui enfrentaram o mesmo dilema: para sobreviver no topo da pirâmide revolucionária era indispensável uma lealdade bifronte, ao Partido e a Fidel. Comunistas como Aníbal Escalante e J oaquín 0 rdoqui, mais leais à instituição que ao caudiIho, caíram nos primeiros anos da experiência revolucionária. $N$ acionalistas como Armando $\mathrm{H}$ art eAlfredo Guevara, leais a ambos os poderes, sobreviveram até seu final. 0 conflito entre duas ideologias tão incompatíveis, como o nacionalismo e o comunismo, havia se dirimido al guns anos antes, ao fragor de guerras civis na Espanha e na C hina (cf. Thomas, 1995, pp. 309-334; Salisbury, 1992, pp. 12-17). Em Cuba, não obstante, a hierarquização das lealdades em torno da figura de Fidel Castro permitiu que os discursos se fundissem em uma simbologia única. Tanto é assim que entre 1959 e 1961 negar 0 anticomunismo de C astro era tão grave quanto questionar seu comunismo depois da aliança definitiva com a U nião Soviética.

0 curioso é que a partir de 1961, estabelecido o marxismo-leninismo como ideologia oficial, C arlosR afael Rodríguez demonstrou ser o comunista maisflexível de todos os ex-integrantes do PSP. Em 1965, em razão da constituição do novo partido, Rodríguez sequeixou, numa entrevista aosjornalis- 
tas norte-americanos Richard Elder do $\mathrm{N}$ ew York Times, Alvin Burt do M iami H erald e Lyle Stuart do TheI ndependent, da "rigidez doutrinária" do marxismo soviético. "O sinstrumentos da educação caracterizam-seem muitos assuntos por enfoques dogmáticos" - dizia Rodríguez - e demandava uma formação marxista heterodoxa dos economistas cubanos. "Como ser, em filosofia, um bom marxista e ao mesmo tempo não ser dogmático?" perguntava-se- eagregava sua decepção diante da maioria dos livros de filosofiamarxista procedentes daU nião Soviética: "Faz anosquetento encontrar um bom livro marxista sobre K ant, etudo que encontro éuma repetição de queK ant era agnóstico e que Engels dizia que o agnosticismo é uma espécie de 'materialismo envergonhado'" (Rodríguez, 1983, vol. II, pp. 442-443).

No caso de Rodríguez, a flexibilidade doutrinária provinha do período pré-revolucionário, quando publicou alguns textos pouco ortodoxos se comparados com trabalhos de Blas Roca ou Aníbal Escalante da mesma época. Em "As classes na Revolução Cubana" (1941), Rodríguez havia destacado o papel da crescente pequena burguesia. Em outro texto pré-revolucionário, "O pensamento dajuventude ortodoxa” (1949), havia criticado 0 "socialismo" ea "democracia" defendidos por jovens ortodoxos como o próprio Fidel Castro, que anos depois se converteria em seu chefe. E, inclusive, numa interessante nota sobre o Redescobrimento de $D$ eus, Rodríguez se dava ao luxo de polemizar civilizadamente com o católico Rafael García Bárcena sobrea "extrapolação deH usserl" ea "racionalização dafé". Tudo isso dentro de uma aplicação cuidadosa, nada mecânica, do marxismo-leninismo à história de C uba, que partia do suposto de que $M$ arx não havia compreendido o problema colonial, essencial para um país latino-americano e caribenho como Cuba (cf. Idem, vol. I, pp. 15-29; 61-76; 243-254; 306-310).

M arxistas como Juan M arinello, Carlos Rafael Rodríguez, José Antonio Portuondo e M irta Aguirre haviam demonstrado antes da Revolução uma marcada tendência ao liberalismo cosmopolita em cultura, advertindo sobre os perigos de um nacionalismo provinciano ou de um dogmatismo ideológico. Um discurso a propósito do trigésimo aniversário da revista $\mathrm{N}$ uestro T iempo, de $\mathrm{C}$ arlos R afael Rodríguez, resume essa idéia marxista do "nacional na cultura" por meio de uma crítica paralela do nacionalismo ético e da ortodoxia ideológica. D izia então que "a cultura nacional énacional na medida em que a essência própria seja capaz de expressar-se, nos modos mais diferentes e universais. Se se aprofunda bem na própria nação, se chega por esse caminho a outra parte, ao encontro com os demais" (H ernández 0 tero, 1989, p. 411). E a propósito do esplêndido livro de osé 
Antonio Portuondo, El heroísmo intelectual (M éxico, Tezontle, 1955), M irta Aguirre havia insinuado que um intelectual comprometido deve combinar a afabilidade, a "transigência liberal", a "prudência erasmista" e, ao mesmo tempo, não "vacilar em indispor-se" e "dizer claramente o que deve dizer" (Idem, p. 105).

No entanto, no momento do triunfo revolucionário, instrumentados já como letrados orgânicos do poder, os marxistas cubanos chocaram-se com os nacionalistas republicanos ( $M$ añach, Lizaso, Ichaso...) e com os novos nacionalistas revolucionários (Franqui, C abrera Infante, Padilla...). Roa, por exemplo, que havia tomado parte do governo deC arlos Prío Socarrás (19481952) como diretor de cultura no M inistério da E ducação, encabeçado por Aureliano Sánchez Arango, e que havia criticado a invasão soviética da H ungria em 1956, arremetia em 1969 contra a "ótica astigmática esensibilidade de pescoço duro" de Indagación del choteo, apesar de ter ele mesmo publicado em 1928, na Revista deAvance, um elogio daquele ensaio clássico e de que, em meados dos anos de 1930, polemizara com o autor de M artí, el A póstol com firmeza e até com crueza, mas sem nunca deixar de reconhecer a honestidade e o talento de M añach (cf. Roa, 1969, p. 24; D íaz, 2003, pp. 95-97). Como recordou $D$ uanel $D$ íaz, nos momentos mais álgidos de suas polêmicas com o $M$ añach do $A B C$ da biografia martiniana, os marxistas cubanos - al guns deles, como M arinello ou Roca, haviam compartilhado posições proeminentes com I chaso e o próprio $M$ añach na Assembléia Constituinte de 1940 eaténo primeiro governo de Batista - sempre admiraram e respeitaram $\mathrm{O}$ autor de $\mathrm{H}$ istoria y estilo. Ainda que José Antonio Portuondo, M irta Aguirre e outros, nos anos de 1970, tenham falado do "diversionismo ideológico" mañachiano nos anos de 1930, 1940 e 1950, M arinello celebrava, "sem adulação de irmãos", cada livro de M añach, e Roa se referia ao "libérrimo juízo das teorias, dos homens e das coisas", à "prosa excelente" e aos "generosos desvelos e esforços por uma Cuba com um mínimo de decência dentro do status colonial em que vive" daquele importante intelectual republicano (cf. Díaz, 2003, pp. 152-155).

0 choque entre liberais republicanos, comunistas pré fidelistas e nacionalistas revolucionários, depois de 1959, adquiriu desde o início tintas de uma fratura geracional. N os três primeiros anos da Revolução, publicações como Lunes de Revolución, La Gaceta de Cuba ou El M undo en D omingo refletiram essa disputa entre os letrados tradicionais da República e os intelectuais orgânicos do novo regime revolucionário. Em Lunes, por exemplo, os jovens poetas $\mathrm{H}$ eberto Padilla e Antón Arrufat questionaram a modera- 
ção de $M$ añach, 0 apelo recorrenteà decência cívica, como uma indefinição diante do regimerevolucionário, um "ficar em cima do muro" e, sobretudo, um preconceito reacionário contra o novo. $M$ añach, que surgira como intelectual trinta anos antes, à frente de uma geração vanguardista e revolucionária, era visto agora pelos jovens intelectuais de 1959 como conservador e até mesmo misoneísta (cf. Padilla, 1959a, 1959b; Arrufat, 1959).

Entre março de 1959 e novembro de 1961, os 129 números de Lunes de Revolución apresentaram o maior esforço de pluralidade e vanguarda da política cultural do novo regime. Basta lembrar que a publicação ocupou-se de temas tão cosmopolitas e heréticos, da perspectiva de um marxismo ortodoxo ou de um nacionalismo estreito, como o nazismo e o franquismo, os direitos humanos e a tradição socialista, África el srael, a reforma agrária ea identidadenacional, Ballagas e Borges, C amus eSartre, a U nião Soviética ea C hina, cinema e teatro, Estados U nidos e M éxico, a Segunda Guerra M undial ea Guerra Civil Espanhola, Picasso eC apablanca (cf. Luis, 2003, pp. 57-135). No entanto, o impulso de ruptura, de ajuste de contas com 0 passado, manifesto na última edição de Ciclón, acompanhava Lunes desdeo primeiro número, em que aparecia um duro ataque de Enrique Berros contra Cintio Vitier, a propósito de Lo cubano en la poesía (cf. Berros, 1959). Artigos como "El club de los moderados", de C ésar Leante, no número 37 (30/11/1959), "Las armas dela reacción", de Antón Arrufat, no número 38 (7/12/1959), "Prensa imparcial, un concepto falso", de José Barbeito, no número 39 (14/12/1959), ou "Frustración política, conformismo intelectual", deEuclidesV ázquez Candela, no número 45 (1/2/1960), são ilustrativos do compromisso de L unes de Revolución com a destruição das instituições liberais da opinião pública republicana, como D iario de la M arina, e com a expulsão do campo intelectual cubano daqueles que ante os olhos da nova geração revolucionária apareciam como letrados do antigo regime: Baquero, M añach, os dois V itier, Ichaso, Lizaso, C hacón e Calvo...

Em seu último artigo em Bohemia Libre ("José M artí: rompeolas de América"), Jorge M uñach formulou um claro discernimento da tensão entre a legitimidade histórica da Revolução de 1959 e a ilegitimidade política do Socialismo de 1961, esta última entendida, naturalmente, a partir de tradição liberal edemocrática da ordem republicana (cf. M añach, 1961, pp. 7 e95). Ainda que a radicalização socialista do processo revolucionário, claramente perceptível desde o outono de 1960, tenha cindido o campo intelectual entre os que não aceitavam a ilegitimidade do novo regime e os que davam respal do à transformação marxista empreendida pelo jovem líder, os 
três grandes discursos do nacionalismo republicano - o liberal, o católico eo comunista - experimentaram uma curiosa forma de subsistência durante a primeira década socialista. As polêmicas dos anos de 1960, enfrentadas pela nova geração de intelectuais revolucionários (Guillermo Cabrera Infante, Pablo Armando Fernández, Roberto Fernández Retamar, Alfredo Guevara, Tomás Gutiérrez Alea, Lisandro 0 tero, Ambrosio Fornet, Edmundo D esnoes...) contra a velha geração marxista (Juan M arinello, M irta Aguirre, Carlos Rafael Rodríguez, Félix Pita Rodríguez, Edith García Buchaca, José Antonio Portuondo...) e contra a intelectual idade católica que permaneceu em Cuba (José Lezama Lima, JoséM aría C hacón y C alvo, Raimundo Lazo, Cintio Vitier, Fina García M arruz, Eliseo D iego...), foram dealgum modo a continuação, por outros meios, das guerras culturais da República.

A partir de Lunes de Revolución e do último número de Ciclón, ficaram estabelecidas as duas frentes daquelas guerras culturais: o choque geracional e a disputa entre dois modos - o stalinista e o heterodoxo - de assumir a cultura nacional sob o socialismo. D epois da censura a PM e do fechamento de Lunes, em 1961, ea cel ebração, no ano seguinte, do Primeiro Congresso de Escritores e Artistas, que deu lugar à criação da U neac e de seu órgão editorial, La Gaceta de Cuba - que, de acordo com seus editores (N icolas Guillén e Lisandro 0 tero), diferentemente de O rígenes, Ciclón e Lunes, não seria "um espelho para $\mathrm{N}$ arciso, mas forja para Vulcano..., nem seria feito pelo grupo para o grupo, nem obedeceria a igrejinhas ou seitas..." - , as querelas entre as elites não desapareceram, mas se deslocaram para diversos posicionamentos ideológicos e culturais dentro do campo revolucionário e socialista. Assim, é possível detectar elementos geracionais e ideológicos em polêmicas como a que mantiveram Virgilio Piñera, Roberto Fernández Retamar e Gil Blas Sergio nos primeiros números de La G aceta de Cuba (abril-maio de 1962), sobre a literatura anterior e posterior à Revolução e seu maior ou menor grau de compromisso político; no debate sobre o romance No hay problema (1962), de Edmundo D esnoes, em junho desse ano, ena mesma revista entre Virgilio Piñera, Antón Arrufat, $\mathrm{H}$ eberto Padilla, Ambrosio Fornet, César Leante, Lisandro 0 tero e José Soler Puig; na interessante discussão sobre o novo teatro cubano protagonizada por Antón Arrufat, José Ramón Brene, Abelardo Estorino, M. Reguera Saumell, José Triana e Rine Leal, em junho de 1963 e também em La Gaceta; na ampla e intensa polêmica sobre "Cinema e Revolução", desde o verão de 1963 até a primavera de 1964, em várias publicações de H avana (Revolución, H oy, Bohemia, El M undo, La Gaceta de Cuba, 
Cuba Socialista e Cine Cubano), que envolveu jovens cineastas como Tomás Gutiérrez Alea, H umberto Solás, Pastor Vega, Julio G arcía Espinosa, O ctavio Cortázar, Jorge Fraga e Raúl M acías, funcionários e teóricos culturais como Blas Roca, Alfredo Guevara, Edith García Buchaca, M irta Aguirre eSergio Benvenuto; e, por fim, no inteligente debate, em meados de 1964, entre José Antonio Portuondo e Ambrosio Fornet, suscitado pela novela EI derrumbe (1964), de José Soler Puig, e que se estendeu, no caminho, à avaliação de toda narrativa produzida em Cuba depois de $1959^{7}$.

Em 1966, o ficcionista e filósofo Jesús D íaz recebeu a tarefa de editar o suplemento cultural do periódico Juventud Rebelde, órgão da U nião de Jovens Comunistas de Cuba. 0 magazine será conhecido como El Caimán Barbudo, em alusão à geografia da ilha revolucionária, e em seu primeiro conselho editorial intervirão alguns dos escritores mais interessantes daquela geração: Luis Rogelio N ogueras, Guillemo Rodríguez Rivera, Victor Casaus, Elsa Claro e M ariano Rodríguez H errera (cf. Díaz, 2000, pp. 106111). Esse grupo chocou-se com outra fração da mesma geração, formada por poetas negros e homossexuais, ligados à Ediciones El Puente: G erardo Fulleda León, José M ario, N ancy M orejón, Josefina Suárez, Ana M aria Simo...8.

El Caimán Barbudo aspirava realizar uma proeza que já na Rússia dos anos de 1920 resultara impossível: criar um espaço de liberdadee rigor intelectual sob o comunismo. Em seu primeiro número, Jesús D íaz afirmava quea revista era "obra de jovens revolucionários, comprometida com a Revolução, com seu Partido, o queéigual a estar comprometido com averdade ecom a arte". M ais adiante advertia que os editores estavam "conscientes de que os dogmas não fazem senão frear sempreo desenvolvimento da cultura" e, evocando Antonio M achado, concluía que "escrever para o povo era chamar-se Cervantes na Espanha, Shakespeare na Inglaterra, Tolstoi na Rússia" ${ }^{\prime}$. N em mais nem menos que o sonho de uma vanguarda heterodoxa, que deslumbrou M aiakovski e Gorki, e que Lênin eStalin converteram em pesadelo.

No entanto, na $\mathrm{H}$ avana dos anos de 1960 podia-se sonhar com uma cultura crítica, refinada, que partilhasse os valores social istas da Revolução e, ao mesmo tempo, recusasse os impul sos totalitários da nova elite do poder. A estrutura doutrinária e institucional do comunismo soviético ainda não se transportara para a ilha, ea esquerda intelectual na América Latina e na Europa (Paz e Sartre, Vargas Llosa e C alvino, C ortázar e Sontag...) via em Cuba um experimento social, nacionalista e justo, que não sucumbiria
7. La Gaceta de Cuba, n. 2, 1 o maio 1962, pp. 2-7; n. 3, 15 maio 1962, pp. 4-5 e 15-16; n. 4, 5 jun. 1962, pp. $5-$ 6; n. 19, 3 jun. 1963, pp. 3-6; n. 23, 26, 27, 28, 29, 30, 31, 32 e33, de ago. 1963 a mar. 1964; n. 39, 5 jul. 1963, pp. 6-8 e9-11; n. 40, out. 1964, pp. 6-7; n. 41 , nov. 1964, pp. 12-16. Sobrea polêmicaarespeito decinema, ver também Guevara (1998, pp. 201-218).

8.Ver o dossiê "R epasar el puente", em La Gaceta de Cuba, n. 4, jul.-ago. 2005, pp. 236.

9.El Caimán Barbudo, n. 1, mar. 1966, p. 1, La H abana. 
ao feitiço da Europa do Leste. O s intelectuais cubanos mais suspicazes, Guillermo Cabrera Infante, Carlos Franqui e H eberto Padilla, também apostaram nesse socialismo libertário até a perseguição, prisão ejulgamento do último, entre 1967 e 1971.

Em 1967, a revista El Caimán Barbudo publicou um artigo de H eberto Padilla em que ele julgava duramente ("pastiche de Carpentier e Durrell [...], prosa saturada de muletas [...], salto para a banalidade") a novela Pasión de U rbino, de Lisandro 0 tero, então vice-ministro da Cultura, enquanto, para cúmulo, elogiava Tres tristes tigres ("uma das novelas mais brilhantes, mais engenhosas e mais profundamente cubanas jamais escritas [...], plena de verdadeira força juvenil, de imaginação, atrevimento e gênio"), de G uillermo Cabrera Infante, exilado em Londres (cf. Padilla, 1998, pp. 9192). Tres tristes tigres ganhou o prêmio Biblioteca Breve de Seix Barral daquele ano, e a nota de $\mathrm{H}$ eberto Padilla passou à história como 0 único elogio de Cabrera Infante publicado em Cuba nos últimos quarenta anos. Jesús D íaz foi afastado da direção de El Caimán Barbudo por haver autorizado a publicação daquele merecido elogio.

Entre 1967 e 1971, Jesús Díaz envolveu-se em outra aventura intelectual sob o comunismo cubano, a revista Pensami ento C rítico. Essa publicação, dirigida pelo filósofo Fernando $M$ artínez e editada pelo D epartamento de Filosofia da Universidade de La H abana, propunha-se divulgar "0 desenvolvimento do pensamento político e social do tempo presente" esuas

10.Pensamiento CrítiCo, n. 1, fev. 1967, La H abana, Instituto del Libro. contribuições para a "Cuba revolucionária"10. Alentada pela busca de um socialismo autônomo, distante de M oscou e de Pequim, a revista tentou oferecer à Revolução um discurso heterodoxo, em que confluía a tradição nacionalista e latino-americanista do pensamento cubano (Varela, M artí, Varona, Guerra, O rtiz...) com o marxismo e o liberalismo ocidentais de Gramsci e Lukács, de Althusser e $M$ arcuse, de Korch e Bloch, Adorno e Sartre, H obsbawn eAron (cf. Díaz, 2000, pp. 111-119). Justamentequando as elites havanesas forjavam uma aliança definitiva com a U nião Sovié tica, anunciada já pelo apoio de Fidel C astro à invasão soviética da T che coslováquia, aqueles jovens arriscaram-se a urdir uma conexão cubana com o maio de 1968. Paradoxos da esquerda: enquanto Cuba era um símbolo nas ruas de Paris, Praga e M éxico, na $\mathrm{H}$ avana oficial a causa do maio de 1968 era percebida como uma ameaça.

Pensamiento Crítico editou números impactantes para o meio intelectual e político dailha em finais dos anos de 1960: o número 18/19 de 1968, por exemplo, dedicou-se ao estruturalismo e à lingüística no teatro, história, 
cinema e literatura, com ensaios de autores franceses como Jean Cuisenier, M arc Barbut, Paul Ricoeur, M ichel D elahaye, Jacques Rivette, Lucien Sebag e H enri Lefebvre (pp. 3-7); o número 21 desse mesmo ano reproduzia a entrevista de Jean-Paul Sartre à revista Le Point, "El intelectual frente a la Revolución", em que ele dava respaldo à revolta estudantil de Paris, e incluía também vários estudos sobre as duas Alemanhas (pp. 191-205); 0 número 30, de 1969, era dedicado à cibernética (pp. 3-4); 0 34/35, desse mesmo ano, trazia ensaios de Robin Blackburn e Perry Anderson sobre cultura e nação e o estudo de François $G$ eorge sobre Althusser (pp. 3-51); ou o número 39, de 1970, dedicado à Revolução de 1930, com textos de EnriqueJ oséVarona, G abriela M istral, Eduardo C hibás, Pablo delaTorriente Brau e Antonio Guiteras (pp. 104-105, 214-216, 321-322).

U m rápido percurso por aquelas polêmicas, e outras que viriam depois, como as de U nión, Casa de las Américas e El Caimán Barbudo, permitiria dividir as posições em três grandes blocos heterogêneos einorgânicos: 0 dos criadores de diversas gerações, provenientes alguns de publicações como O rígenes, Ciclón e Lunes, que defendiam uma cultura socialista nacional e cosmopolita, com certa margem de autonomia diante do poder e desligada de rígidas formulações classistas e ideológicas (Virgilio Piñera, $\mathrm{H}$ eberto Padilla, J osé Rodríguez Feo, Tomás Gutiérrez Alea, Antón Arrufat, Rine Leal, Edmundo Desnoes, Ambrosio Fornet...); o dos teóricos e burocratas da cultura, seguidores do marxismo ortodoxo soviético e do realismo socialista, e associados fundamentalmente ao velho Partido Comunista (Juan $\mathrm{M} \mathrm{a-}$ rinello, Blas Roca, M irta Aguirre, N icolás Guillén, JoséAntonio Portuondo, Edith García Buchaca...); eo dos políticos e intelectuais que, ainda que não comungassem com as teses da ortodoxia soviética, aspiravam a uma estética realista queabasteceria as demandas simbólicas da revolução (A rmando H art, $\mathrm{H}$ aydéeSantamaría, Alfredo Guevara, Roberto Fernández Retamar, Lisandro O tero...). C como se sabe, depois de um breve predomínio do segundo grupo na direção cultural do país, o terceiro, sempre em luta com a ortodoxia marxista e, ao mesmo tempo, vigilante e repressivo em relação às dissidências do primeiro bloco, acabaria ganhando a liderança de instituições como a C asa de las Américas e o Icaic e, finalmente, controlando a U neac e 0 M inistério da Cultura. 


\section{Referências Bibliográficas}

Arrufat, Antón. (1959), “Las armas de la reacción”. Lunes de Revolución, 7 dez. Berros, Enrique. (1959), “Un cubano en la poesía”, Lunes de Revolución, 23 mar.

Cabrera Infante, Guilhermo. (1993), M ea Cuba. M éxico, Vuelta.

Carpentier, Alejo. (1984), El siglo de las luces. Barcelona, Seix Barral.

Che Guevara, Ernesto. (1971), El socialismo y el hombre en Cuba. M éxico, Grijalbo.

D íaz, D uanel. (2003), M añach o la república. La H abana, Letras Cubanas.

D íaz, Jesús. (2000), "El fin de otra ilusión”. Encuentro de la cultura cubana, n. 16/

17, pp. 106-111, primavera/verão, M adri.

D omínguez, Jorge. (1978), Cuba: order and revolution. H arvard University Press, The Belknap Press.

El Caimán Barbudo, n. 1, mar. 1966, p. 1, La H abana.

Franco, Jean. (2004), D ecadencia y caída de la ciudad letrada: América Latina en la Guerra Fría. Barcelona, D ebate.

Fran qui, Carlos. (1972), "Respuesta de Carlos Franqui”. Libre, fev., pp. 9-10,

Furet, François. (1995), El pasado de una ilusión. M éxico, FCE.

García Borrero, Juan Antonio. (2001), Guía crítica del cine cubano de ficción. La

$\mathrm{H}$ abana, Editorial Arte y Literatura.

GILMAN, Claudia. (2003), Entre la pluma y el fusil: debates y dilemas del escritor revolucionario en América Latina. Buenos Aires, Siglo XXI.

Gram ScI, Antonio. (1971), La política y el Estado moderno. Barcelona, Península.

Guevara, Alfredo. (1998), Revolución es lucidez. La H abana, Ediciones ICAIC.

H abel, Jinete. (1965), Proceso al sectarismo. Buenos Aires, Jorge Alvarez.

Hernández O tero, Ricardo (org.). (1989), Revista Nuestro Tiempo, Compilación de trabajos publicados. La H abana, Letras Cubanas.

La Gaceta de Cuba, n. 2, 1 - maio 1962, pp. 2-7; n. 3, 15 maio 1962, pp. 4-5 e 1516; n. 4, 5 jun. 1962, pp. 5-6; n. 19, 3 jun. 1963, pp. 3-6; n. 23, 26, 27, 28, 29, 30, 31, 32 e 33, de ago. 1963 a mar. 1964; n. 39, 5 jul. 1963, pp. 6-8 e 9-11; n. 40, out. 1964, pp. 6-7; n. 41, nov. 1964, pp. 12-16.

LuIS, W illiam. (2003), Lunes de Revolución: literatura y cultura en los primeros años de la Revolución Cubana. Madri, Verbum.

M AÑACH, Jorge. (1961), “José M artí: rompeolas de América”. Bohemia Libre, 23 jul., pp. 7 e 95.

M arinello, Juan. (1984a), "Sobre la Revista de Avance y su tiempo". In: O bras. Cuba: Cultura. La Habana, Letras Cubanas, pp. 90-107. . (1984b), "A medio siglo de la Revista de Avance". In: O bras. Cuba: Cultura.

La H abana, Letras Cubanas, pp. 273-303. 
M artínez Perez, Liliana. (2006), Los hijos de saturno: intelectuales y revolución en Cuba. M éxico, Porrúa.

Padilla, H eberto. (1959a), "M añach y la M arina”. Lunes de Revolución, 2 nov. . (1959b), "La poesía en su lugar". Lunes de Revolución, 7 dez. . (1998), Fuera del juego. Edición conmemorativa, 1968-1998. M iami, Ediciones Universal.

Pensamiento Crítico, n. 30, 30 jun. 1969, pp. 3-4, La H abana; n. 39, abr. 1970, pp. 104-105, 214-216 e 321-322; n. 1, fev. 1967, Instituto del Libro; n. 18/19, 1968, pp. 3-7, Instituto del Libro; n. 34/35, nov.-dez. 1969, pp. 3-51; n. 21, 1968, pp. 191-205, Instituto del Libro.

Q uintero Herencia, Juan Carlos. (2002), Fulguración del espacio: letras eimaginario institucional de la revolución cubana (1960-1971). Buenos Aires, Beatriz Viterbo.

ReEd, Roger. (1991), The cultural revolution in Cuba. University of Geneva Press, Latin American Round Table.

RoA, Raúl. (1969), La revolución del 30 se fue a bolina. La Habana, Instituto del Libro.

Rodriguez, Carlos Rafael. (1983), Letra con filo. La Habana, Editorial de Ciencias Sociales, vol. II.

RojAs, Rafael. (1999), Isla sin fin: contribución a la crítica del nacionalismo cubano. M iami, Ediciones Universal.

_. (2006), Tumbas sin sosiego: revolución, disidencia y exilio del intelectual cubano. Barcelona, Anagrama.

Ruız, Ramón Eduardo. (1972), Cuba: génesis de una revolución. Barcelona, Editorial Noguer.

Salisbury, H arrison Evan. (1992), The new emperors: China in the era of $M$ ao and Deng. Londres, Little, Brown and Company.

Stable, Marifeli Pérez. (1998), La revolución cubana: orígenes, desarrollo y legado. M adri, Editorial Colibrí.

Staro bin SkI, Jean. (1988), 1789. Los emblemas de la razón. M adri, Taurus.

ThомAs, Hugo. (1995), La guerra civil española. Barcelona, Grijalbo M ondadori, vol. I.

Veigas, José, Vives, Cristina \& N odal, Adolfo. (2002), M emoria: cuban art of the 20th Century. International Arts Foundation.

Verdés-Leroux, Jeannine. (1989), La lune et le caudillo: le rève des intellectuels et le régime cubain (1959-1971). Paris, Gallimard. 


\section{Resumo}

Anatomia do entusiamo: cultura e revolução em Cuba (1959-1971)

$N$ as duas décadas que antecederam a revolução de 1959 em Cuba constituiu-se um campo intelectual, similar ao descrito por Pierre Bourdieu para a alta modernidade européia, baseado na autonomia da esfera pública, nas instituições acadêmicas e no mercado. 0 triunfo revolucionário e a radicalização socialista dos anos de 1960 transformaram esse campo por meio de uma politização da sociedade que, ao mesmo tempo que destruía e alargava as hierarquias e os limites sociais da cultura, reduzia a autonomia do campo e a pluralidade ideológica dos discursos nacionais. 0 objetivo deste artigo é investigar a reacomodação experimentada pelas relações entre os intelectuais e o poder durante a primeira década da revolução cubana.

Palavras-chave: Revolução; Intelectuais; Revistas; Periódicos; Literatura; Arte; Crítica.

\section{Abstract}

An anatomy of enthusiasm: culture and revolution in Cuba (1959-1971)

The two decades preceding the Cuban revolution of 1959 saw the constitution of an intellectual field - one similar to the field of high European modernity described by Pierre Bourdieu - based on the autonomy of the public sphere, on academic institutions and on the market. The revolutionary triumph and the socialist radicalization of the 1960s transformed this field through a politicization of society that, while destroying the culture's hierarchies and expanding its social limits, reduced the autonomy of the field and the ideological plurality of national discourses. The objective of this article is to investigate the re-adaptation undergone by the relations between intellectuals and the ruling elite during the first decade of the Cuban revolution. Keywords: Revolution; Intellectuals; M agazines; Periodicals; Literature; Art; C riticism.

Texto recebido em 14/ 2/2007 e aprovado em $14 / 2 / 2007$.

Rafael Rojas é doutor em H istória pelo Colégio do M éxico e professor visitantena Universidade dePrinceton. E-mail: rrojas@prince ton.edu. 